\title{
Risk factors associated with subclinical mastitis in dairy cows reared in district Ganderbal, Jammu and Kashmir
} \author{
Division of Veterinary Biochemistry, SKUAST-Kashmir, J\&K, India.
}

Citation: Ali, A., Ganie, S.A., Mir, M. R., Ahmad, S.B., Bhat, R.R. and Mir, B.A. 2021. Risk factors associated with subclinical mastitis in dairy cows reared in district Ganderbal, Jammu and Kashmir. J. Vet. Anim. Sci. 52(4): 418-422

DOI: https://doi.org/10.51966/jvas.2021.52.4.418-422

Received: 15.09.2021

Accepted: 12.10.2021

Published: 15.012.2021

\begin{abstract}
Subclinical mastitis is associated with certain risk factors such as age, lactation stage, milk production and parity. A cross sectional study including 135 cross bred Holstein Friesian dairy cows was undertaken from June 2017 to January 2019 in surrounding villages of district Ganderbal in order to identify major risk factors. The overall prevalence of SCM was $81.48 \%$. The highest prevalence of subclinical mastitis associated with various risk factors was $48.1 \%$ (early lactation), $44.54 \%$ (5-7 years), $49.09 \%$ (>10 litres per day) and $30.90 \%$ (3 $3^{\text {rd }}$ parity) respectively. In intensive system of rearing, prevalence was $66.36 \%$ whereas in extensive $33.63 \%$ was found. In present study, single quarter was affected in $61.81 \%$ of SCM infections. In milking method, knuckling and stripping showed more incidence of SCM. In present study, moderate form of mastitis was more predominant (40.9\%).
\end{abstract}

Keywords: Subclinical mastitis, lactation, parity, milk production

Running title: Association of risk factors in dairy cows

Globally India is the largest milk producer with majority of population dependent on agriculture and animal rearing for earning their livelihood. India has 190 million cattle and 108 million buffaloes with dairy cows accounting for $43 \%$ and buffaloes $53 \%$ of the total milk production. Bovine mastitis is inflammatory disease of udder and characterized by swelling, pain, fever, redness, heat, clots in milk. Mastitis is a multietiological disease with bacteria being the most common etiological agent. Other than bacteria, others pathogens like mycoplasma, yeast and in minor cases viral

1. Ph.D Scholar (Department of Clinical Biochemistry, University of Kashmir, J\&K)

2. Assistant Professor (Department of Clinical Biochemistry, University of Kashmir, J\&K)

3. Professor and Head

4. Professor

5. Guest lecturer

6. Ph. D Scholar

${ }^{*}$ Correspondence: showkatganie786@yahoo.com, Ph. +917006784320

Copyright: (0) 2021 Ali et al. This is an open access article distributed under the terms of the Creative Commons Attribution 4.0 International License (http://creativecommons.org/licenses/by/4.0/), which permits unrestricted use, distribution, and reproduction in any medium, provided the original author and source are credited. 
agents have been found. There are two forms of mastitis, clinical mastitis (CM) and subclinical mastitis (SCM) (Duguma et al., 2014). Subclinical mastitis is the predominant form of mastitis and the disease is present without any noticeable signs, which makes it difficult to diagnose (Ali et al., 2017). In SCM, the milk composition is altered with 15-45 decrease in milk production (Halasa et al., 2007). Despite many years of research predisposing factors like improper management, poor hygiene, teat damage, defective milking machines, parity, lactation, breed, age and milk production are associated with incidence of SCM. Effective environmentalawareness, bettermanagemental practices with good sanitation procedures can help veterinarians to decrease the prevalence of subclinical mastitis. Because of the diverse agro-climatological conditions in India, it is essential to know the risk factors of SCM in a particular area in order to implement proper planning for therapeutic and control measures. The present study aimed to determine the risk factors associated with SCM in Holstein Friesian cattle.

The present study was carried in different regions of district Ganderbal, Jammu and Kashmir ( $\mathrm{J} \& \mathrm{~K}$ ) with lactating Holstein Friesian dairy crossbred cows being found in the study area during June 2017 to January 2019. In this cross-sectional study, 135 Holstein Friesian crossbred dairy animals were selected with the aim to determine association of risk factors with subclinical mastitis. With visual inspection, the physical examination of milk samples was conducted to determine any color deformity, purity, odor, flakes, clots, blood or any other noticeable difference in appearance. The dairy animals were properly screened for SCM based on clinical examination and CMT and grouped into healthy and subclinical animals.

The overall prevalence of subclinical mastitis was $81.4 \%$ in this study. Out of 110 SCM cases, 53, 34 and 23 mastitis milk samples belonged to early (1-3months), mid (4-6months ) and late lactation (7-9months) stages. The highest incidence was found in early lactation stage (48.1\%) followed by mid lactation $(30.90 \%)$ whereas lowest prevalence was reported in late lactation stage $(20.90 \%)$. In present study, dairy cows in the early stage of lactation were affected more with SCM in comparison to mid and late stages of lactation. The present reports are in agreement with previous studies (Gupta et al., 2017 Swami et al., 2017; Maheshwari et al., 2016; Islam et al., 2011; Mohana Sundhari, 2010) respectively. The high incidence of SCM during early lactation stages could be due to rapid physiological changes in postpartum tissues of mammary gland, thus leading to constant stress and decreased immune status (Shaikh et al., 2018).

The present result indicates that among 110 CMT positive HF dairy cows, 22 cases belonged to 2-4 age group, 49 to 5-7 years, 28 to $8-10$ years and 11 to $>10$ age group respectively. Table 2 , represents the relation between SCM and age group. The incidence of SCM in this study was more in 5-7 (44.54\%) age group followed by $8-10$ (25.45\%), 2-4 (20\%) and lowest occurrence in $>10(10 \%)$ years of age group. Similar findings of high prevalence in the age group of 5-7 years have been reported (Tiwari et al., 2013; Islam et al., 2011; Maheshwari et al., 2016). The reason for this could be efficient innate defense system in younger animals that render them less susceptible to mastitis infection, whereas reduced milk yield, improper animal handling, decreased milking practice may reduce infection chances in older animals.

The incidence of SCM in this study was more in $5-7(44.54 \%)$ age group followed by $8-10(25.45 \%), 2-4(20 \%)$ and lowest occurrence in $>10(10 \%)$ years of age group. Similar findings of high prevalence in the age group of 5-7 years have been reported (Tiwari et al., 2013; Islam et al., 2011; Maheshwari et al., 2016). The reason for this could be efficient innate defense system in younger animals that render them less susceptible to mastitis

Table 1. Number of mastitis quarters affected in study area

\begin{tabular}{|c|c|c|}
\hline $\begin{array}{c}\text { No. of quarters } \\
\text { affected }\end{array}$ & $\begin{array}{c}\text { No. of } \\
\text { animals }\end{array}$ & Prevalence\% \\
\hline 1 & 68 & 61.81 \\
\hline 2 & 29 & 26.36 \\
\hline 3 & 9 & 8.18 \\
\hline 4 & 4 & 3.63 \\
\hline
\end{tabular}


Table 2. Incidence between milking method and SCM

\begin{tabular}{|l|l|c|c|}
\hline \multirow{4}{*}{ Milking method } & & No. of SCM cases & Prevalence \% \\
\cline { 2 - 4 } & Full hand milking & 16 & 14.54 \\
\cline { 2 - 4 } & Knuckling & 60 & 54.54 \\
\cline { 2 - 4 } & Stripping & 27 & 24.54 \\
\cline { 2 - 4 } & Machine milking & 7 & 6.36 \\
\hline
\end{tabular}

In SCM infected animals, Table 3, respectively, represents the nature of mastitis.

Table 3. Nature of SCM cases in study area

\begin{tabular}{|l|c|c|}
\hline Nature of SCM & $\begin{array}{c}\text { No. of SCM } \\
\text { cases }\end{array}$ & Prevalence \% \\
\hline Mild & 28 & 25.45 \\
\hline Moderate & 45 & 40.9 \\
\hline Severe & 37 & 33.63 \\
\hline
\end{tabular}

infection, whereas reduced milk yield, improper animal handling, decreased milking practice may reduce infection chances in older animals.

In SCM infected Holstein Friesian dairy cows, 18 cases belonged to 1-5 litres milk yielding group, 38 to $6-10$ and 58 animals to $>10$ liters per day yielding group. The present study reported highest prevalence in dairy cows with milk yield of $>10$ litres ( $49.58 \%$ ) followed by $6-10$ litres $(34.1 \%)$ and lowest occurrence in $>1-5$ litres $(16.32 \%)$. The finding of present study are in agreement with previous reports (Islam et al., 2011; Barua et al., 2014; Sharma et al., 2018; Tiwari et al., 2008). The stress produced by over production and increased loss of micronutrients that have role in immunity, may predispose animals to intramammary infections. Further, a genetic correlation has been found between milk yield and causation of mastitis in dairy cattle.

In dairy cows, the parity-wise cases recorded were 18, 30, 34, 16, 8 and 4 during the parity numbers 1, 2, 3, 4, 5 and 6 respectively. In this study, parity wise incidence of SCM was found to be highest in $3^{\text {rd }}$ parity $(30.90 \%)$ followed by $2^{\text {nd }}$ parity whereas lowest occurrence was found in $6^{\text {th }}$ parity dairy cows. Maheshwari et al., (2016) and Islam et al., (2011) recorded similar observations. During $3^{\text {rd }}$ parity there is high yielding stress on udder causes the broadening of teat canal due to the pressure on teat sphincter resulting in increased chance of microbe entry and hence increased the chance of infection (Maheshwari et al., 2016).
In intensive system, 73 dairy cows were positive for SCM whereas in extensive system 37 animals were infected. The incidence of SCM infection in intensive and extensive system is shown in Table 5 . The prevalence of SCM was more in intensive system (66.36\%) as compared to extensive system (33.63\%). Poor hygienic conditions and big herd size with less spacing may be related with high incidence in intensive as compared to extensive. Abdurahman, (2006) reported poor milk hygiene associated with high incidence of mastitis in dairy animals.

In the present study, 135 Holstein Friesian dairy cows were screened for SCM with 110 positive for mastitis. Table 1shows the prevalence of quarters affected. In this study, single quarter showed more incidence of SCM infection (61.81\%) followed by two quarters (26.36\%). Yohannis et al., (2013) have reported similar findings. The high quarter wise prevalence may be due to poor udder health and improper managemental practices.

The relationship between incidence of SCM and milking methods is shown in Table 2. In the present study, knuckling and stripping caused more damage to udder tissues leading to mastitis. This in concordance to report of Suresh et al., (2017). The reason for this could be poor hygiene of milker's hand and improper udder washing.

\section{Summary}

In dairy cows, the primary risk factors that are associated with occurrence of SCM are lactation, age, increased milk production and parity. The prevalence study indicates that early lactating cows, 5-7 age group, milk production greater than 10 litres per day and dairy animals in $3^{\text {rd }}$ parity were more susceptible to subclinical mastitis. The study also indicated that dairy 
cows in intensive system of rearing were more prone to mastitis. This study also revealed that infections in single quarters, knuckling method and moderate form of mastitis were commonly reared in the selected area. To prevent animals from SCM infection, it is important to identify the risk factors of the disease. Management and poor feeding practices may greatly influence the risk factors among dairy cattle. Therefore, preventive measures like cleaning of teat before milking with clean water, washing of milker's hands, farm hygiene, improvement in milk technique and proper diagnostic techniques are fundamentally important in minimizing the mastitis infections.

\section{Acknowledgment}

The authorsare thankful to Department of Science and Technology (Govt. of India) for funding (2016-2019). The author is also highly thankful to Dr. Showkat Ahmad Ganie and Dr. Manzoor ur Rahman Mir who provided full support for conducting this research work.

\section{Conflict of interest}

The authors declare that they have no competing interests

\section{References}

Abdurahman, O.A. 2006. Udder health and milk quality among camels in the Errer valley of eastern Ethiopia. Liv. Res. Rur. De.v, 18(8): 110.

Ali, A., Mir, B. A., Bhat, R. R., Baba, O. K., Hussain, I., Rashid, S. M., and Mir, M. U. R. 2017. Metabolic profiling of dairy cows affected with subclinical and clinical mastitis. J Entomol. Zool. Studies, 5(6): 1026-1028

Barua, M., Prodhan, M. A. M., Islam, K., Chowdhury, S., Hasanuz zaman, M., Imtiaz, M. A., and Das, G. B. 2014. Subclinical mastitis prevalent in dairy cows in Chittagong district of Bangladesh detection by different screening tests. vet. World, 7(7):483-488.

Duguma A, Tolosa T and Yohannes. 2014. Prevalence of clinical and subclinical mastitis on crossbred dairy cows at Holleta Agricultural research Centre, Central Ethiopia. J. Vet. Med. Anim, 6: 13- 17.

Gupta, S., Kotwal, S. K., Singh, S. G., Ahmed, T., Kour, A., and Anand, A. 2017. Epidemiological study on mastitis in holstein friesian cattle on organized farm in Jammu, India. Theriogenol. Insight, 7(1): 5-11.

Halasa T, Huijps K, Osteras O and Hogeveen. 2007. Economic effects of bovine mastitis and mastitis management- $A$ Review. Vet.Quart., 29: 18- 31

Islam, M. A., Islam, M. Z., Rahman, M. S., and Islam, M. T. 2011. Prevalence of subclinical mastitis in dairy cows in selected areas of Bangladesh. Bangladesh. J. Vet. Med., 9(1): 73-78.

Maheshwari, P. A. W. A. N., Shukla, P. C., Rao, M. L. V., and Shukla, S. N. 2016. Occurrence of subclinical mastitis in cattle in and around Jabalpur, Madhya Pradesh. Haryana Vets, 55(2): 160-162.

Mohana Sundhari.2010.Diagnostic sensitivities of culture and polymerase chain reaction in bovine mastitis. M.V.Sc., Thesis submitted to Tamilnadu Veterinary and Animal Sciences University, Chennai, India.

Shaikh, S. R., Digraskar, S. U., Siddiqui, M. F., Borikar, S. T., Rajurkar, S. R., and Suryawanshi, P.R.2019.Epidemiological studies of mastitis in cows reared under different managemental system in and around Parbhani. J. Pharm. Innov., 8(2): 01-05.

Sharma, A., Chhabra, R., Singh, M., and Charaya, G. 2018. Prevalence, etiology and antibiogram of bacterial isolates recovered from mastitis of buffaloes. Buffalo Bull, 37(3): 313-320.

Suresh M, Muhammed Safiullah AH, Kathiravan G, Narmatha N. 2017. Incidence of Clinical Mastitis Among Small Holder 
Dairy Farms in India. J. Vet. Sci., 12(1):113.

Swami, S. V., Patil, R. A., and Gadekar, S. D. 2017. Studies on prevalence of subclinical mastitis in dairy animals. J. Entomol. Zool. Stud., 5(4): 1297-1300.

Tiwari, J. G., Babra, C., Tiwari, H., Williams, V., De Wet, S., Gibson, J., and Mukkur,
T. 2013. Trends in therapeutic and prevention strategies for management of bovine mastitis: an overview. J. Vaccines Vaccination, 4(1): 1-11.

Yohannis M, Molla W. 2013. Prevalence, risk factors and major bacterial causes of bovine mastitis in and around Wolaita Sodo, Southern Ethiopia. Afr. J. Microbiol. Res., 7(48): 5400-5405. 